\title{
A Deep Outlook for the Chalcopyrite Solar Cells: For Future Perspectives
}

\author{
Songul Fiat Varol ${ }^{1,}$, , Guven Cankaya ${ }^{2}$ \\ ${ }^{1}$ Energy Systems Engineering, Faculty of Engineering, Giresun University, Giresun, Turkey \\ ${ }^{2}$ Materials Engineering, Faculty of Engineering and Natural Sciences, Ankara Y1ldırım Beyazıt University, Ulus/Ankara, Turkey
}

Email address:

songulvfiat@yahoo.com (S. F. Varol)

${ }^{*}$ Corresponding author

\section{To cite this article:}

Songul Fiat Varol, Guven Cankaya. A Deep Outlook for the Chalcopyrite Solar Cells: For Future Perspectives. International Journal of Energy and Power Engineering. Special Issue: Renewable Energy Resources and Power Generation. Vol. 8, No. 4, 2019 , pp. $52-65$. doi: 10.11648/j.ijepe.20190804.14

Received: June 29, 2019; Accepted: September 24, 2019; Published: October 24, 2019

\begin{abstract}
This publication investigates to present all new scientific and industrial works all rolled into one with more effective and predictability aspect in chalcopyrite Photovoltaics (PVs). The paper suggests that comprehensive and fine-tuned directions supporting a large portfolio of solar energy materials could be extended to most efficiency, which mostly depend on the growth techniques especially usage rates in substituents and their characteristic/specific properties. There is an indispensable source of solar energy. If this were the case, new energy materials could well become a competitive alternative in many applications within the next few years. This publication builds upon past analyses of chalcopyrites contained in the word Energy outlook as efficient alternative materials. It aims at offering an updated picture of current technology trends/demands/markets, as well as new analyses on how solar energy technologies/materials for capturing the purposed efficiency and durableness can be used in the various energy consuming/developing sectors, now and in the future. In this work we have tried to summarize the all significant studies about Chalcopyrite solar cells from the past to the present and also tried to introduce Te doped CuInGaSeTe compound which is a new member of the family that we produced.
\end{abstract}

Keywords: $\mathrm{Cu}(\mathrm{In})(\mathrm{Ga})(\mathrm{Se})(\mathrm{S})$, Chalcopyrite Compounds, I-III-VI Semiconductors, Photovoltaics (PVs)

\section{Introduction}

Solar energy technologies have witnessed many attempts to find/develop new trends such as Silicon (with CuZnS, CdO:In), CdTe, organic/polymer solar cells, quantum dot solar cells, perovskites, silicon-perovskite tandem devices and the renewed interest in chalcopyrites [1-8]. Will they now fulfill their promise to deliver affordable, highly efficient, accessibility to sources and clean energy materials? Which solar technologies are really close to competitiveness, in which circumstances and for which applications? What kind of policy/roadmap support do they require and for how long?

The rapid evolution of these technologies brings tangible answers and datas to those questions unusually difficult. Up to now, only a limited number of countries have been supporting most of the effort to drive solar energy technologies to competitiveness. Concerns about new material types, growth methods and characterizations have also sometimes led to abrupt new revisions in scientific area. Enterprises/policies may lapse or lose momentum just a few years before they would have succeeded. The costs of solar energy have been falling rapidly and are entering new areas of competitiveness. In this regard, the scientists set off on a guest to find new, easily processable PV materials and systems with more affordable prices [9-11].

The development of photovoltaic device structures based on CIGS has advanced rapidly during the last few years. The direct energy gap of CIGS results in a large optical absorption coefficient, which permits the use of thin layers of active material, and allows high-device performances in spite of the modest carrier diffusion lengths. The highest efficiency CIGS device was fabricated based on a multi-step physical vapor deposition (PVD) process in which elements are simultaneously co-deposited onto the substrate. Unfortunately, PVD is challenging to scale up in 
both deposited area and throughput. Process temperatures also tend to be high, which complicates use of polymer substrates and permits interdiffusion of layers in superstrate device geometries. Thus, to develop novel low cost and low temperature methods to form CIGS films is crucial. A related high-priority issue in CIGS PV technology is improving the understanding of thin-film growth mechanisms in both traditional and novel processes and schemes [8, 12-16] (see Figure 1).

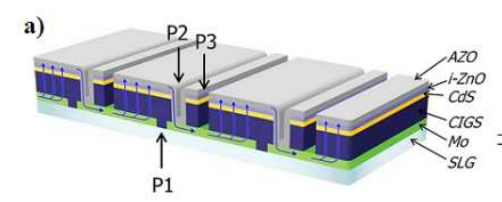

c)

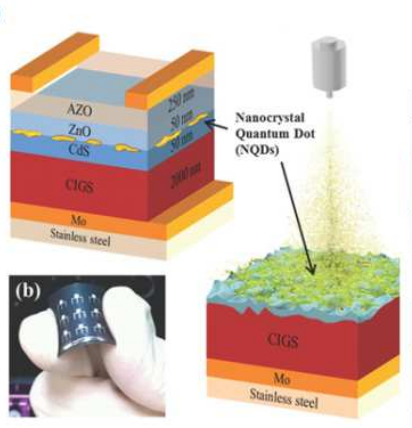

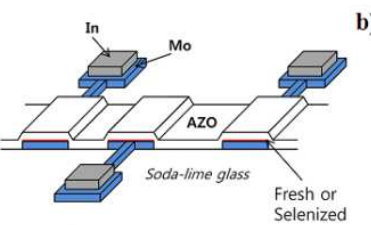

d)

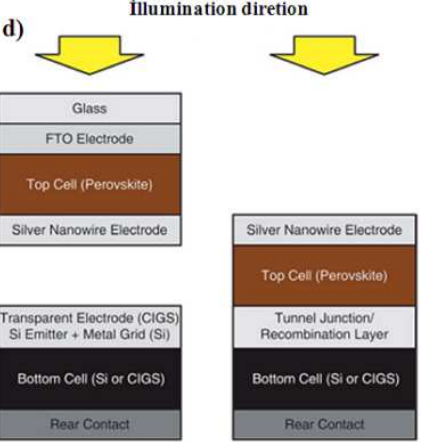

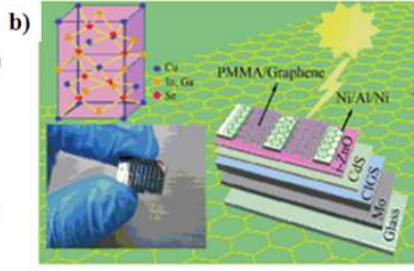

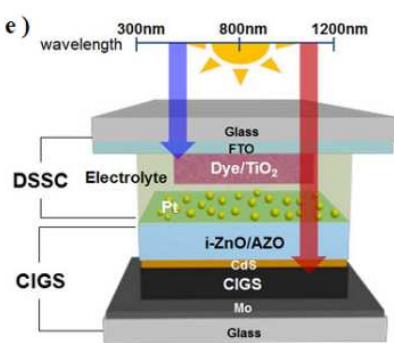

Figure 1. Schematic illustrations of various schemes for tandem chalcopyrite solar cells layouts and methods: a) a monolithically integrated CIGS solar module, indicating the photocurrent path and Illustration of the inverse Transmission Line Method TLM (i-TLM) sample used to measure the AZO/Mo contact resistance. b) Schematic structure of the graphene-based CIGS solar cell (left) and the reference CIGS solar cell with a standard TCE structure (right). c) Schematic illustration of a flexible inkjet-printed NQD/CIGS hybrid solar cell deposited by pulsed-spray NQD deposition system. d) Tandem schematics. Schematic of a mechaniicallystacked tandem fabricated in this work with a perovskite solar cell asthe top cell and Si or CIGS as the bottom cell (left). Schematic of a monolithic polycrystalline tandem (right). e) Schematic of the DSSC/CIGS tandem solar cell structure [8, 12-16].

It is good news that the quality of the CIGS films and devices is becoming increasingly decoupled from the method of film delivery because of improved understanding of growth. Chalcopyrite PVs have progressed from first proof of concept on melt-grown crystals to high-efficiency thin film laboratory devices [17-19] to manufacturing presently in the hundreds of MW range. Manufacturing volumes are expected to push into the gigawatt $(\mathrm{GW})$ range in coming years due to the combination of relatively high efficiency (compared to $\mathrm{CdTe}$ or $\alpha-\mathrm{Si}$ ) and potentially low processing costs (compared to single-crystal Si) (Figure 2). However, much work remains to be done.

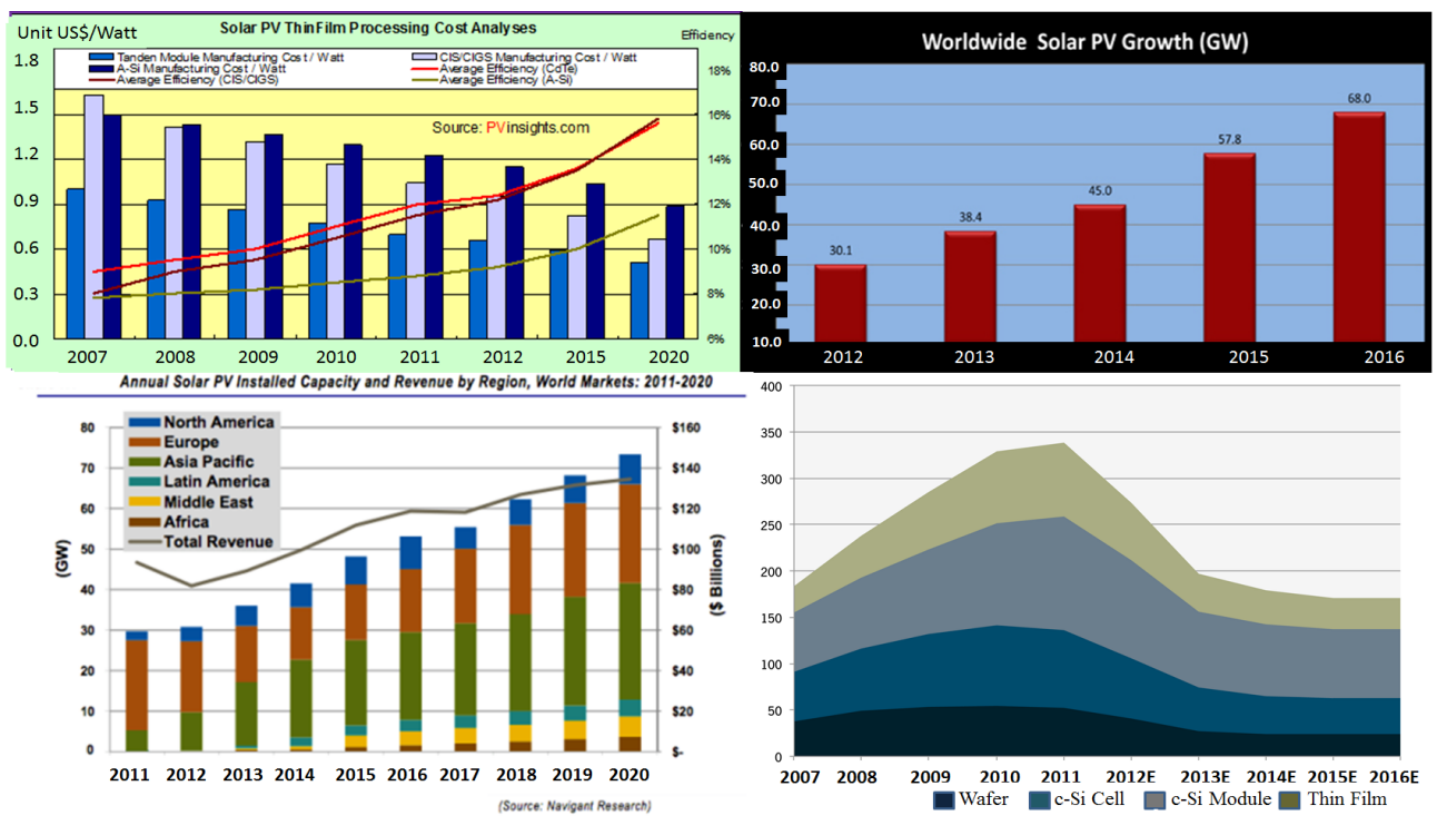

Figure 2. PV Manufacturing facilities from different aspects (cost, regional, energy and material type) in worldwide (pvinsights.com/Report/ReportPM.php (2016), solarcellcentral.com/markets_page.html (2016), cleantechnica.com/2013/11/13/global-solar-pv-installations-will-double-hit-grid-parity-by-2020 (2016), Number of Active PV Manufacturing Facilities, Ingot-to-Module, 2007-2016 (GTM Research's report, titled PV Technology, Production and Cost: 2012-2016 Outlook, 2012)). 


\section{Comments and Discussions}

Deposition Techniques /Efficiencies of Chalcopyrites

Vapor-phase co-deposition of elements deposits the chalcopyrite film atom-by-atom with great precision. There are a number of unresolved questions about how PVD codeposition parameters (e.g., substrate temperature, total- and differential-atomic fluxes, background ambient, and pressure) might be optimized to further improve CIGS film quality. Multi-step sequential vapor-phase processes are arguably better suited than vapor-phase co-deposition to large-scale, low-cost manufacturing. However, much remains to be understood about them. For example, the mechanisms through which Group I-III metal alloy layers react with Group VI elements to form dense, large-grain CIGS films that adhere well to an underlying electrode are incompletely studied. The mechanisms by which the substrate and electrodes affect the characteristics of resulting CIGS films, and how one might optimally select substrates/electrodes and/or tailor CIGS film deposition processes to surrounding materials need work. Optimal use of alkali metals to improve film quality and achieving desired composition grading in multi-step processes would also benefit process designs and schemes. Given the industrial importance of vapor-phase co-
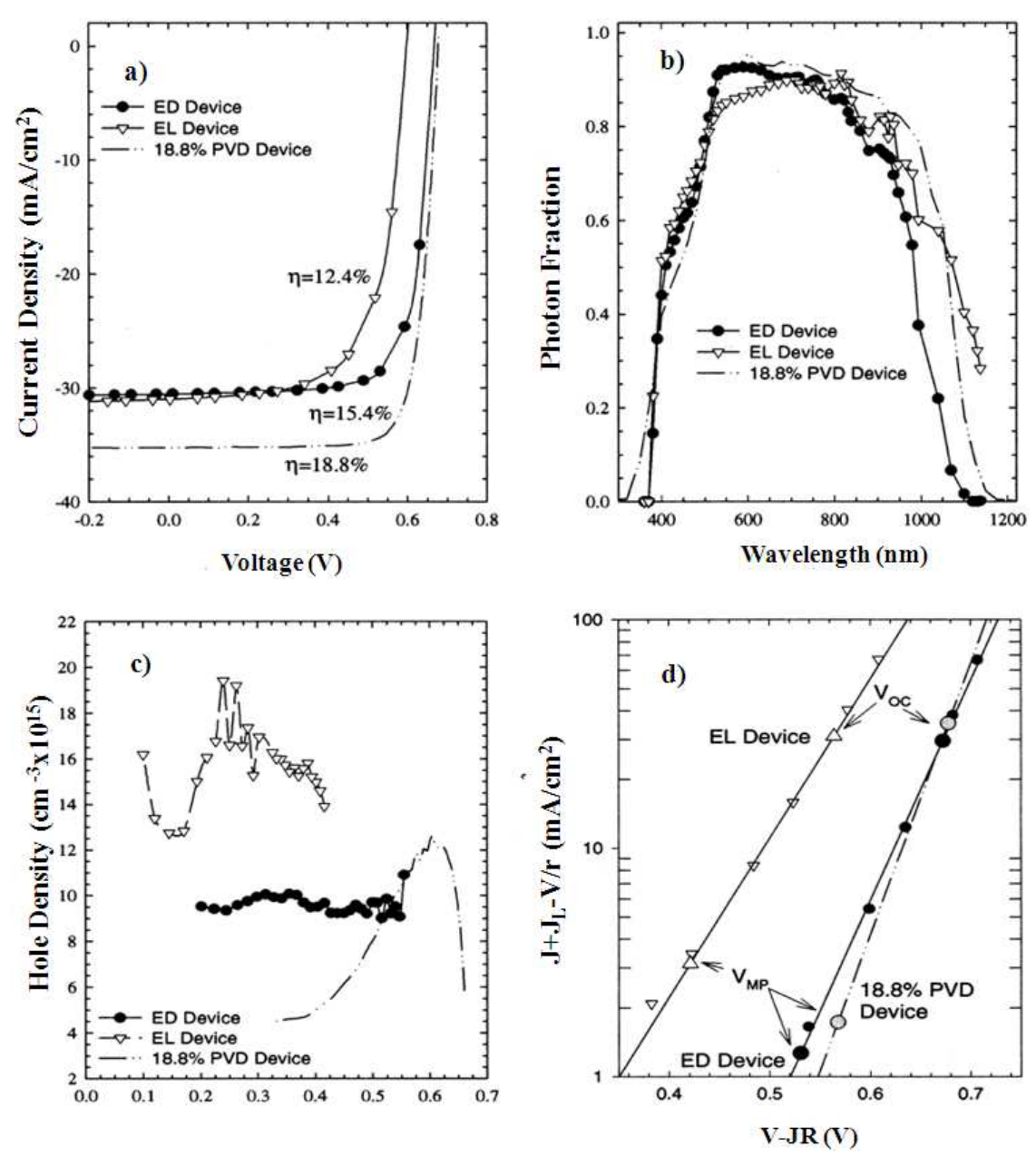
(summarized in Table 1).

Figure 3. a) Current-voltage (I-V) characteristics of ED, EL and PVD devices. b) Quantum efficiency data. c) Hole density vs. distance curves. d) Logarithmic I-Vcharacteristics with resistive losses removed [22].

deposition and multi-step processes, there is great leverage in their better understanding. Vapor-phase co-deposition and multi-step processes have in common the use of vacuum deposition techniques, which have numerous advantages, including precision composition control, a broad base of processing know-how, and a knowledge base for design of research and production-scale equipment. In addition, vacuum deposition suffers from high up-front capital equipment costs. A variety of novel film-deposition methods promise to replace capital-intensive physical vapor deposition with non-vacuum deposition of constituent layers and/or complete CIGS device. Currently, a great deal of effort is being made to develop such low-cost technologies. Processes based on electrodeposition (ED), electrolessdeposition (EL), and nano particle-based processes have the potential for: (i) a low-cost, high-rate synthesis of CIGS; (ii) large-area, continuous, multi-component, low-temperature depositions; (iii) non-vacuum, low-capital-cost processes; and (iv) efficient material use. The devices fabricated using ED, EL, and nano particle precursors resulted in efficiencies of $15.4 \%, 13.4 \%$, and $12.4 \%$, respectively (Figure 3) 
Table 1. Parameters of the devices prepared from electrodeposition precursor (ED device), electroless-deposition precursor (EL device) and physical vapor deposition (PVD device) [22].

\begin{tabular}{llll}
\hline Cell & ED device & EL device & PVD device \\
\hline $\mathrm{Ga} /(\mathrm{In}+\mathrm{Ga})$ & 0.4 & 0.20 & 0.28 \\
Area $\left(\mathrm{cm}^{2}\right)$ & 0.418 & 0.418 & 0.432 \\
$\operatorname{Voc}(\mathrm{V})$ & 0.666 & 0.565 & 0.678 \\
$\mathrm{Jsc}\left(\mathrm{mA} / \mathrm{cm}^{2}\right)$ & 30.51 & 33.27 & 35.2 \\
$\operatorname{Vmax}(\mathrm{V})$ & 0.554 & 0.434 & 0.567 \\
$\mathrm{Jmax}\left(\mathrm{mA} / \mathrm{cm}^{2}\right)$ & 27.8 & 28.6 & 34.5 \\
$\mathrm{FF}(\%)$ & 75.6 & 66.1 & 78.6 \\
$\operatorname{rshunt}\left(\mathrm{Vcm}^{2}\right)$ & 2000 & 1000 & 10000 \\
Rseries $\left(\mathrm{Vcm}^{2}\right)$ & 0.3 & 0.1 & 0.2 \\
İdeality Factor $(\mathrm{A})$ & 1.8 & 2.5 & 1.5 \\
Depletion width $(\mathrm{mm})$ & 0.2 & 0.25 & 0.5 \\
Hole density $\left(\mathrm{cm}{ }^{-3}\right)$ & $1.0 \times 10^{16}$ & $1.5 \times 10^{16}$ & $1.0 \times 10^{16}$ \\
Band gap $(\mathrm{eV})$ & 1.20 & 1.09 & 1.12 \\
Efficiency $(\%)$ & 15.4 & 12.4 & 18.8 \\
\hline
\end{tabular}

Table 2 shows the relative contributions of the primary solar-cell parameters to the lower performance seen in the ED and EL cells [20-22].

Table 2. Comparison of primary ED and EL parameters with the record $18.8 \%$ - efficient PVD cell [22].

\begin{tabular}{lll}
\hline & $\begin{array}{l}\text { ED vs. PVD } \\
\text { (adjusted for Eg) }\end{array}$ & $\begin{array}{l}\text { EL vs. PVD } \\
\text { (adjusted for Eg) }\end{array}$ \\
\hline Efficiency difference (\%) & $3.4(3.4)$ & $6.4(6.4)$ \\
Difference from Voc (\%) & $0.3(1.4)$ & $2.5(2.1)$ \\
Difference from Jsc (\%) & $2.3(1.2)$ & $0.8(1.2)$ \\
Difference from FF (\%) & $0.8(0.8)$ & $3.1(3.1)$ \\
\hline
\end{tabular}

Investigations on ED-based processes and subsequent annealing led to efficiency improvements up to $11.3 \%$ in 2004 [23]. In the 90s, NREL developed an alternative hybrid method to improve cell efficiencies further. It included an
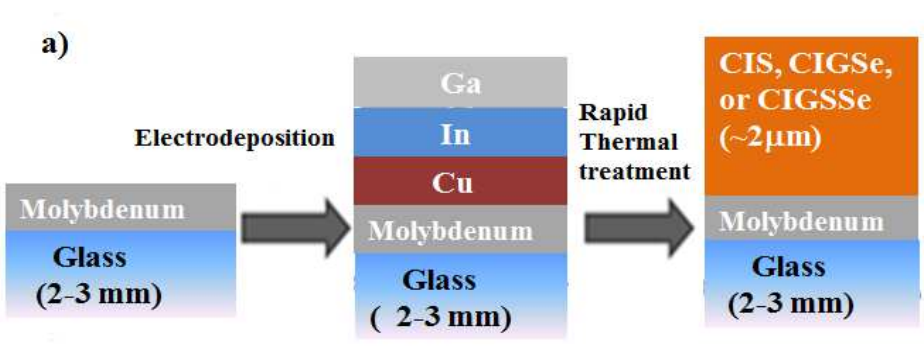

b)
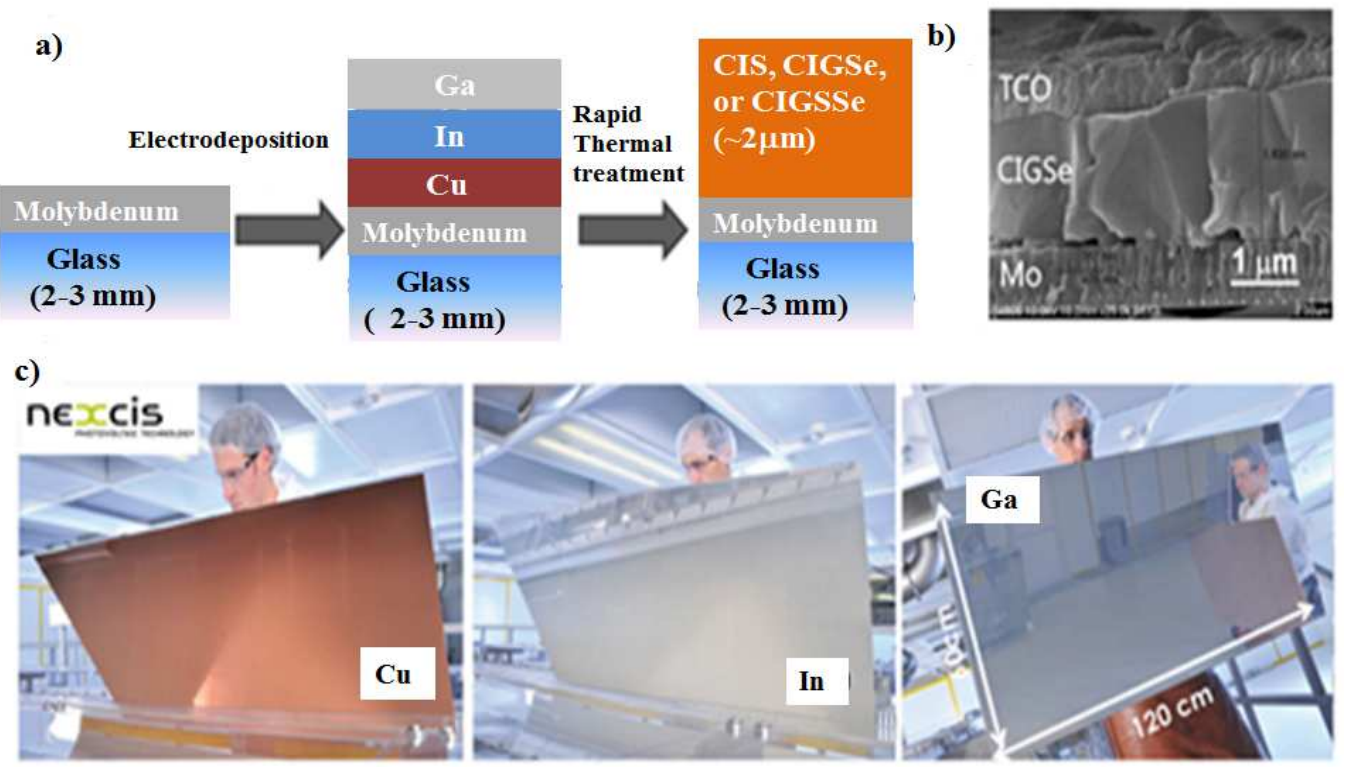

Figure 4. a) Sequential electrodeposition of $\mathrm{Cu}$, In, and Ga metal layers from aqueous solutions, followed by rapid thermal treatment in seleniumcontaining atmosphere to obtain the crystalline chalcogenide layer. b) SEM cross-section of the complete solar cell. c) Photographs of Cu, In, and Ga electrodeposited metallic layers for $60 \times 120 \mathrm{~cm}^{2}$ commercial CIGS modules [30]. additional annealing step while co-evaporating In, Ga and Se in order to tune the stoichiometry of the absorber resulting in efficiency cells can be obtained from ED precursors even though the NREL process still involved a vacuum step. Another hybrid approach with one step electrodeposited $\mathrm{Cu}-$ In-Ga oxide precursor, which was reduced in hydrogen and then annealed in selenium, yielded a $12.4 \%$ CIGS cell [24]. Persistent industrial research of electrodeposited $\mathrm{Cu} / \mathrm{In} / \mathrm{Ga}$ stacks enabled the fabrication of electrodeposition-based CIGS cells with efficiencies of $15.3 \%$ and $15.8 \%$ by Solopower and Nexcis, respectively [25, 26].

Solopower ED process includes several steps where a tayer is electrodeposited first, followed by form the CIGS absorber. Nexcis uses a versatile process of the successive electrodeposition of $\mathrm{Cu}$, In and $\mathrm{Ga}$ elemental layers from water-based solutions (Figures 4a,c), which can be subsequently reacted either into $\mathrm{CuInS}_{2}$, [27] $\mathrm{Cu}(\mathrm{In}, \mathrm{Ga}) \mathrm{Se}_{2}$ [28] or $\mathrm{Cu}(\mathrm{In}, \mathrm{Ga})(\mathrm{S}, \mathrm{Se})_{2}$ [26] during RTA between 500 and $600^{\circ} \mathrm{C}$ in a chalcogen containing atmosphere under the atmospheric pressure and without the use of hazardous gases (e.g., $\mathrm{H}_{2} \mathrm{~S}$ and $\mathrm{H}_{2} \mathrm{Se}$ ). One of the strengths of this ED process is that the precursor can be with a tunable compositional gradient across the absorber thickness. The annealing serves for grain growth and can also be used to re-organize elements in the absorber, which is particularly important for the two-step processes where Ga is known to segregate towards the back contact. The successive $\mathrm{ED}$ and chalcogenation of $\mathrm{Cu}$-In-Ga layers yield absorbers with tightly stacked grains in the micrometer range (Figure 4b) similar to the morphology of PVD-grown material. efficiencies of up to $15.4 \%$ [20]. That proved that high (t) easily engineered to deposit the $\mathrm{Cu}-\mathrm{In}-\mathrm{Ga}$ elemental layers 
Table 3 presents a comparison of optoelectronic parameters for high-efficiency CIGS cells prepared by coevaporation (the $20.4 \%$ solar cell from Empa) on a flexible polymer foil [29, 30] and ED [26]. The main difference between co-evaporation and ED cells is in open-circuit voltage Voc and fill factor FF being lower for the ED cell. The difference in Voc is due to a lower content of gallium in the ED absorber, which results in a lower band gap of 1.01 $\mathrm{eV}$ versus the band gap of $1.12 \mathrm{eV}$ for the evaporated absorber. Noteworthy, the difference between Eg/q and the Voc is $0.39 \mathrm{~V}$ for both the evaporated as well ED cells, indicating a comparable quality and number of voltagelimiting defects in both CIGS materials. To match the Voc of the co-evaporated cell the ED process must be tuned to produce an absorber with a higher gallium or sulfur content to catch a band gap close to $1.1-1.15 \mathrm{eV}$ while keeping defects at the same low level. Further improvements of ED devices can be envisaged when applying the potassiuminduced surface modification recently reported for evaporated absorbers [29]. High deposition rate and high material utilization are two important advantages of ED as compared to other vacuum and non-vacuum techniques. The deposition of each of $\mathrm{Cu}$, In and Ga layers takes only a few tenths of seconds, and the material utilization of In and $\mathrm{Ga}$ species in the bath is expected to reach $95 \%$ in full production. One of the often encountered arguments against ED is that it is less homogeneous than PVD processes because the ED growth is strongly dependent on local substrate conductivity [30].

Table 3. Comparison of photovoltaic parameters of two high efficiency CIGS solar cells where the CIGS absorber is deposited by co-evaporation and electrodeposition. The electrodeposited cell has a lower band gap Eg due to a lower Ga content [26, 29, 30].

\begin{tabular}{lllllll}
\hline Method & Efficiency $(\%)$ & Voc $(\mathbf{m V})$ & Jsc $\left(\mathbf{m A} / \mathbf{c m}^{\mathbf{2}}\right)$ & FF $(\%)$ & Eg/q-Voc $(\mathbf{m V})$ & Ref. \\
\hline Co-evaporation & 20.4 & 736 & 35.1 & 78.9 & 384 \\
Electrodeposition & 15.8 & 619 & 34.6 & 73.8 & {$[29]$} & 390 \\
\hline
\end{tabular}

Such novel techniques offer a variety of potential advantages, but in general they are much less mature -both from the standpoint of basic science understanding and from the standpoint of empirically developed standard recipes. For example, the mechanisms of nanoparticles layer densification and grain growth are not yet clear. As with studies of vacuum processes, there is significant leverage in exploring non-vacuum processes in more detail. On the other hand, recently, a method based on sputtering from a quaternary CIGS target has been proposed as an alternative method to fabricate small CIGS devices and large scale modules. The crystallinity of the asdeposited CIGS film from sputtering is often poor. To improve

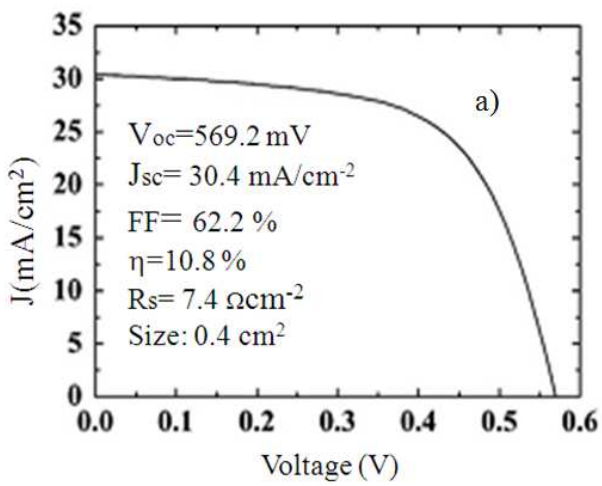

the crystallinity of the absorbers, a post-thermal treatment (selenization process) for as-deposited CIGS absorbers is usually introduced in the film preparation or a high substrate temperature above $500^{\circ} \mathrm{C}$ must be used during the sputtering process (without a selenization process) [31, 32]. These works have recorded the properties of the CIGS absorbers and have successfully applied this method to the fabrication of solar-cells. However, the achieved efficiency is relatively low so far $(10.8 \%$ for the method with a post-selenization and $10.14 \%$ for the method without a post-selenization as seen in Figure 5) [31-35] compared with the method of coevaporation and postselenization of metallic precursors.

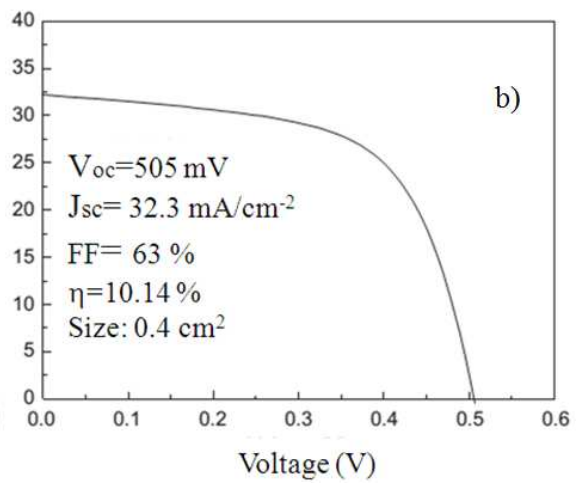

Figure 5. Current Density-Voltage plots of CIGS solar cells treated with selenization (for ' $a$ ') and without post-selenization (for ' $b$ ') methods [32, 34].

Among these growth techniques, electron beam evaporation (e-beam evaporation) mustn't be ignored as significant advantages in terms of high directionality, stoichiometry and purity of the films. Similarly to flash evaporation, in electron beam evaporation, a high thermal density develops over a small region of the source and ensures complete evaporation of the compound target material, without discrimination with respect to the vapor pressures of the individual elements. Electron beam evaporation thus avoids the secondary process of selenization usually observed in the preparation of CIGS films by other methods. Here, in this point we expanded the number of elements for chalcopyrite structured material with an appropriate stoichiometry that are preferred in PV devices by adding Tellurium as addition. This critical advance is enabled primarily by a new set of essential sample preparation protocols, which we presented in our previous work [36]. In fabrication process, $\mathrm{CuIn}_{0.7} \mathrm{Ga}_{0.3}\left(\mathrm{Se}_{0.4} \mathrm{Te}_{0.6}\right)_{2}$ compounds (with 
high purity elemental copper $(\mathrm{Cu})$, indium (In), gallium $(\mathrm{Ga})$ selenium (Se) and tellurium (Te)) have been synthesized in a carbon coated quartz ampoule in order to prevent the reaction between elements and the walls of the ampoule, as well as to avoid their contamination. Then we systematically investigated $\mathrm{Te}$ added CIGSeTe (with annealing effect) materials that exhibit strong correlation with PV performance irrespective of the processing method used to make the absorber layer with $1.13 \mathrm{eV}-1.04 \mathrm{eV}$ optical band gap supports strong light absorption property in the relevant solar emission spectrum.

A major issue in any manufacturing environment is the ability to assess the product performance nondestructively during processing. The goals of any such analyses are first to produce material within given tolerances reproducibly. Other, it is necessary to control uniformity and defects in the devices to increase product efficiency and performance. To be most effective, the test should be non-destructive so that it can be used on all devices. It should not be performed on occasional test structures. Rather, it should take place at many points during product formation on the normal production material to reduce continued manufacturing on already unsatisfactory devices. Finally, an in-situ analysis should permit feedback control of the process to recover malfunctions as quickly and effectively as possible [21]. This would also increase manufacturing throughput because thinner layers can be deposited in less time so controllability is easier and practicable. Implementation will require the development of thin absorbers without a loss in efficiency, processing robustness, and module reliability. Alternatively, the family of chalcopyrite materials provides a rich set of options for engineering new absorber layers that could mimic the physical properties of CIGS needed to achieve similar remarkable efficiencies but also add important attributes such as avoiding indium, moving to a different bandgap, increasing processing robustness, and providing a clearer path to control of properties needed. To achieve these objectives, the following tasks must be addressed: (i) Enhance module efficiency, (ii) Improve module manufacturing processes, (iii) Discover alternative approaches and new materials, and (iv) Assess and interact that includes developing modeling and improved metrics [37, 38].

As seen in Figure 1a, there is a monolithically integrated CIGS solar module and this designing sequence was as follows: A Mo back contact was deposited onto the SLG substrate and scribed using laser ablation along identically spaced patterns (P1 scribing). CIGS/CdS/i-ZnO was sequentially deposited onto the Mo back-contact and mechanically scribed (P2 scribing) using the spacing used during P1 scribing. Finally, the TCO front window layer was deposited on top

of the device and mechanically scribed (P3 scribing). To the researchers, monolithic integrated modules (as shown in Figure 1a) include additional contacts within the P2 scribed area consisting of $\mathrm{TCO} / \mathrm{Mo}$, which may degrade the performance of the module to a greater or lesser degree. It has been challenging to determine whether the P2 region truly limits the achievement of high-efficiency modules. For this matter, they proposed the use of a simple method for evaluating the $\mathrm{P} 2$ contact resistance to avoid special sample fabrication steps and to utilize the existing module structure. The method described here corrected several parasitic components to obtain the exact resistance. These components first addressed in this work and variations has been made on the geometric dimensions of the test structure but tried to reduce the differences between the resistance values measured along different dimensions, and they discussed the parasitic errors of the proposed method in an attempt to calculate the true contact resistance. So they also explored the origin of the $\mathrm{P} 2$ contact resistance. In the absence of this approach, these measurements were very difficult to make in monolithic integrated modules [8]. In this frame, as a 'wonder' material, since it was awarded the Nobel Prize in 2010, graphene also found its position in CIGS technology. Yin et al., demonstrated a novel transparent conducting electrode (TCE) structure consisting of a doped graphene film and a thin layer of poly (methyl methacrylate) (PMMA) to replace the $\mathrm{ZnO}: \mathrm{Al}$ (AZO) electrode for CIGS (Figure 1b). By optimizing the contact between graphene and intrinsic $\mathrm{ZnO}$ (i-ZnO), high power conversion efficiency (PCE) of $13.5 \%$ has been achieved, which is among the highest efficiencies of graphene-based solar cells ever reported and approaching those of AZO-based solar cells [13]. As another new scheme about CIGS PVs, Liao et al. reported on the successful incorporation of self assembled clusters of $\mathrm{CdSe} / \mathrm{ZnS}$ core/shell NQDs into flexible CIGS devices [16]. The nanocrystal quantum dots (NQDs) were embedded between the $\mathrm{CdS}$ buffer and the $\mathrm{ZnO}$ window layer using pulsed-spray deposition (see Figure 1c). They leveraged the poor uniformity of spray deposited NQD layers to engineer an integrated luminescent and light scattering layer of selfassembled NQD aggregates. The nanocrystals were tuned to emit below the band-gap of $\mathrm{CdS}$, with an emission wavelength of $560 \mathrm{~nm}$, and luminescent down-shifting (LDS) is found to provide an important enhancement of the quantum efficiency within the absorption range of the NQDs. The NQD clusters also provide a big rise of the PCE in the red to near-IR spectral range. The NQD aggregates scatter the incident light and displace the absorption closer to the CIGS/CdS interface, where the depletion field is strongest, which consequently increases the average extraction efficiency of the photogenerated carriers. In their work, a 2 $\mu \mathrm{m}$ thick CIGS layer capped with a $50 \mathrm{~nm} \mathrm{CdS}$ thin film was studied before and after deposition of 9 pulses of NQDs. The weak dark-green non-uniform PL signal in the bare sample (Figure 6a) is attributed to the bulk CdS emission. The hybridized sample exhibits bright emission from a nonuniform mesh of NQD aggregates as shown in Figure 6b. Micrometer-wide features spanning 10 to $100 \mu \mathrm{m}$ in length can be observed. Such a morphology is characteristic of the self-assembly of spray deposited NQDs during solvent evaporation [39]. The lateral size of the NQD aggregates was further investigated using cross-sectional TEM in two 
CdS/CIGS p-n junctions coated with 9 and 17 pulses of NQDs (Figures $6 \mathrm{c}$, d). In these images, the NQD aggregates are visible as a pale grey region embedded between the darker CdS layer and the black carbon support.
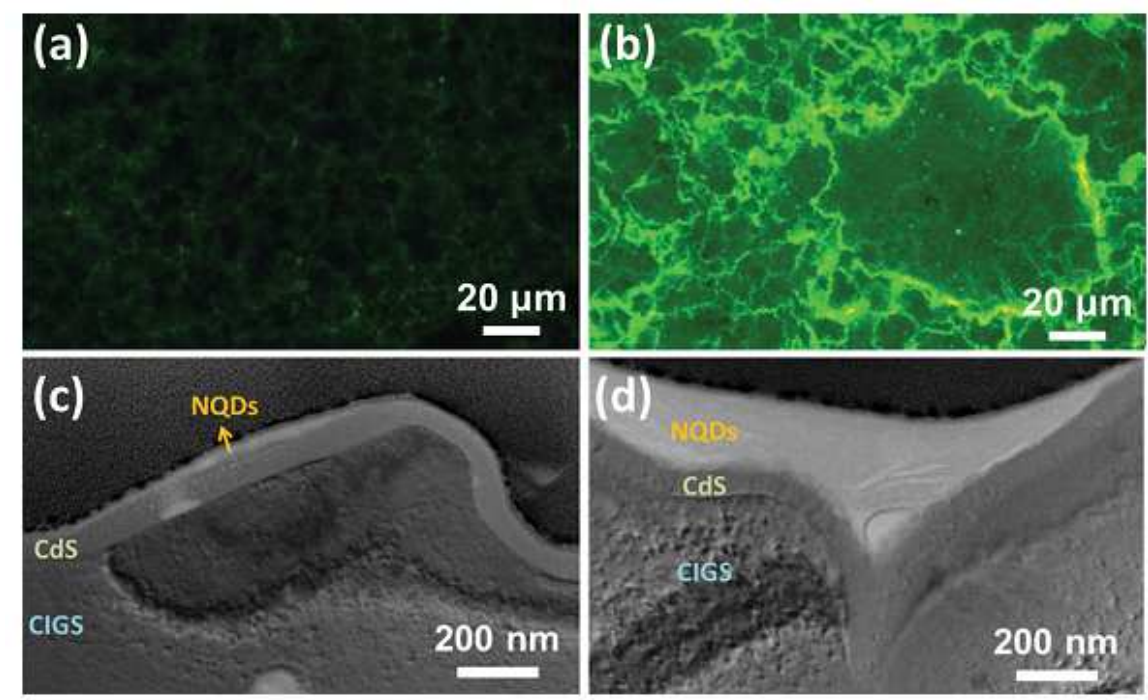

Figure 6. Fluorescence microscopy images of a CdS/CIGS junction a) before and b) after NQD hybridization. Cross-sectional TEM images of CdS/CIGS junctions coated with c) 9 and d) 17 NQD spray pulses [16].

The J-V characteristics of the optimized 9-pulse hybrid solar cell and of its corresponding reference device are presented in Figure 7a. The 9-pulse hybridization is found to provide the best overall performances, with a relative increase in $\mathrm{J}_{\mathrm{SC}}$ of $12.2 \%\left(31.9 \mathrm{mAcm}^{-2}\right.$ to $\left.35.5 \mathrm{mAcm}^{-2}\right)$ yielding a large $10.9 \%$ relative enhancement of the PCE (8.42\% to $9.34 \%)$. The EQE of the 9-pulse hybrid solar cell and its corresponding reference device are presented in Figures $7 \mathrm{a}, \mathrm{b}$ along with the relative EQE enhancement. Hybridization with 9 pulses of NQDs is found to induce two regions of pronounced EQE enhancement at lower and higher wavelengths. The rapid enhancement in the lower part of the spectrum corresponds to the absorption range of the NQDs and is attributed to LDS. The NQDs are directly photoexcited and the resulting photoluminescence is absorbed in the CIGS layer to generate extractable carriers, thus enhancing the overall quantum efficiency of the cell [16].

The development of thin-film solar cells has also been a success story in recent years in terms of record efficiencies in industrial scale. Especially, thin film solar cells based on chalcopyrites are now arriving to a mature state that allows them to be fully manufactured at an. Proof of this are the several records that different companies have achieved, there is MiaSole's $1 \mathrm{~m}^{2}$ with $15.7 \%$ module [40], TSMC Solar's $1.09 \mathrm{~m}^{2} 15.7 \%$ module [41], Solar Frontier's $30 \times 30 \mathrm{~cm}^{2}$ sub-module with $17.2 \%$ efficiency [42], and Solibro's $16 \mathrm{~cm}^{2}$ mini-module with an efficiency of $18.7 \%$ [43], just to name a few. There were recent advances at the laboratory cell level as well, and the world record is now $20.4 \%$ [44, 45] on a flexible substrate. This world record has been achieved by growing CIGS using a co-evaporation method based on the so-called three-stage process [46].
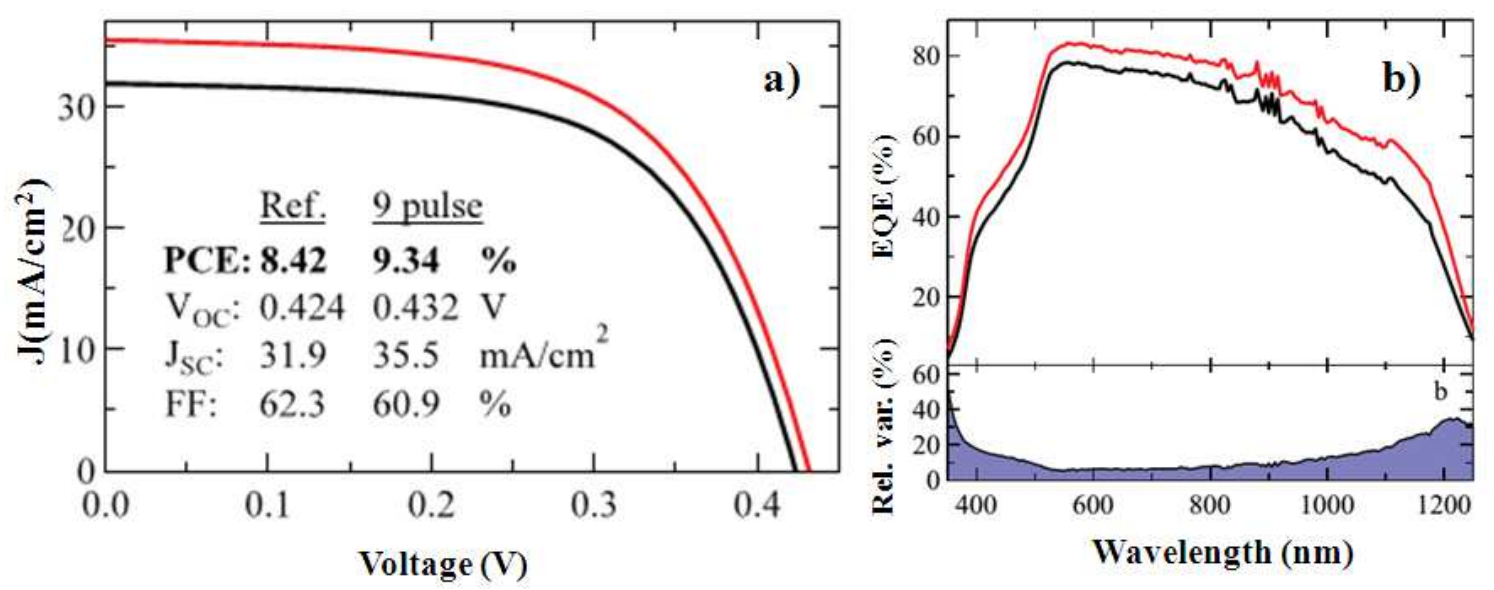

Figure 7. a) EQE of the hybrid (red) and reference (black) devices for a 9-pulse NQD deposition b) Relative EQE enhancement due to hybridization [16].

The industry usually uses one of two concepts to grow CIGS, companies like Solibro, Würth Solar, and Global Solar use co-evaporation, whereas companies like Avancis, Solar Frontier, and Honda Soltec, grow CIGS using selenization of 
precursors The gap in electrical performance between these growth processes seems to be decreasing [47, 48]. Single junction solar cells based on compound semiconductor films now reach higher energy-conversion efficiencies than polycrystalline silicon. Despite this success and the prospect of novel applications such as flexible, lightweight solar panels, the market share of thin-film solar modules is stagnating. The main problem of compound thin-film solar cells, such as $\mathrm{Cu}(\mathrm{In}, \mathrm{Ga}) \mathrm{Se}_{2}$, is the large gap between lab efficiencies and commercial module efficiencies (Table 4).

Table 4. PV efficiencies in lab scale and commercial scale (Source: Fraunhofer ISE, Progress in Photovoltaic).

\begin{tabular}{lll}
\hline Efficiencies & Lab Record & Commercial \\
\hline Solar Cell & $46.0 \%$ (ISE, Soitec, CEA) & $38-43 \%$ \\
Minimodule & $43.4 \%$ (ISE) & N. A. \\
Module & $38.9 \%$ (Soitec) & $27-33 \%$ \\
System (AC) & N. A. & $25-29 \%$ \\
\hline
\end{tabular}

A large process parameter space makes trial-and-error optimization a time-consuming and expensive task. Therefore, understanding the underlying atomic-scale physics and chemistry is essential to identify the potential origins of efficiency losses in the transfer from lab to large scale fabrication $[49,50]$.

Increasing efficiency is particularly important because the cost to install modules now exceeds the cost to make them and the cost of installation effectively drops when the number of panels that needs to be installed to reach a desired power output is reduced. In the last few years, dozens of photovoltaic companies with promising technologies have been forced out of the market. Because new factories desire large amounts of capital to build, startups could not achieve the necessary economies of scale to compete in the marketplace with the amount of capital that the investment community was willing to provide. With this in mind, approaches that involve upgrading the market-leading technologies instead of completely displacing them are highly attractive. The power conversion efficiency of silicon photovoltaics has been stuck at $25 \%$ for more than fifteen years [12]. We believe that a way to improve on this value is to make tandem solar cells in which a top cell with a higher bandgap than silicon absorbs the higher energy photons and generates a voltage that is approximately twice what silicon can generate. It is desirable to make the high bandgap cell at very low cost using a material than can function well even when it is polycrystalline and defective. Recently, a superb candidate, hybrid perovskites, has emerged $[51,52]$. Since their first use in photovoltaics in 2009, the power conversion efficiency of polycrystalline thin film perovskite solar cells has soared to over $20 \%[53,54]$. The first design principle to consider when making tandem solar cells is choosing the right band gaps in order to optimize harvesting of the solar spectrum. It is well known that the bottom cell should have a bandgap around $1.1 \mathrm{eV}$ and the top cell should have a bandgap around 1.7-1.8 eV [55]. Si and CIGS both have an ideal bandgap for the bottom cell. In the relatively few cases where tandems were made with $\mathrm{Si}$ or CIGS, the top cell sometimes had a bandgap of only $1.4 \mathrm{eV}$ simply because there are relatively few high performing PV materials and one of them, CdTe, has that bandgap [56]. Tandems have also been made with dye-sensitized solar cells, but the efficiency was only $16 \%$ [57]. The perovskite semiconductor most commonly used in solar cells is methyl ammonium-lead(II)-iodide with the chemical formula $\mathrm{CH}_{3} \mathrm{NH}_{3} \mathrm{PbI}_{3}\left(\mathrm{MAPbI}_{3}\right)$, which is an inorganic-organic hybrid perovskite that forms a tetragonal crystal structure and is compatible with both solution processing and evaporation methods [58-60]. $\mathrm{MAPbI}_{3}$ is a strongly absorbing direct bandgap semiconductor with $\sim 1.6 \mathrm{eV}[61,62]$. Also, it is an intrinsic material with high carrier mobilities [63], shallow defect levels [64] and $1 \mathrm{~mm}$ carrier diffusion lengths, which are important metrics for highly performing solar cell devices [65]. $\mathrm{MAPbI}_{3}$ devices have obtained large open circuit voltages of $1.07 \mathrm{~V}$, only $0.53 \mathrm{~V}$ less than the bandgap, Eg/q [59]. The bandgap of the $\mathrm{MAPbI}_{3}$ perovskite $(1.6 \mathrm{eV})$ can be continuously tuned up to $2.25 \mathrm{eV}$ by substituting $\mathrm{Br}$ for I to make $\mathrm{MAPb}\left(\mathrm{I}_{1-\mathrm{x}} \mathrm{Br}_{\mathrm{x}}\right)_{3}$ [66], which makes perovskite solar cells especially attractive for tandem applications. A simple stoichiometry of 1:2 bromine to iodine has the ideal bandgap as $1.76 \mathrm{eV}$. A second design principle to consider is how to construct the tandem (Figure 1d). Bailie et al. introduced two options that could be used to make practical modules. The classical method is a monolithically integrated tandem (Figure 1d, right). A more unconventional method is a mechanicallystacked tandem (Figure 1d, left). The mechanically-stacked tandem has the advantage of manufacturing simplicity and ease of integration. A mechanically stacked architecture relaxes performance constraints such as current-densitymatching and the need for tunnel junctions while enabling optimization of the top and bottom cells separately. Current matching between the top and bottom strings of cells can be achieved at the module level by adjusting the relative top and bottom cell sizes (Figure 8).

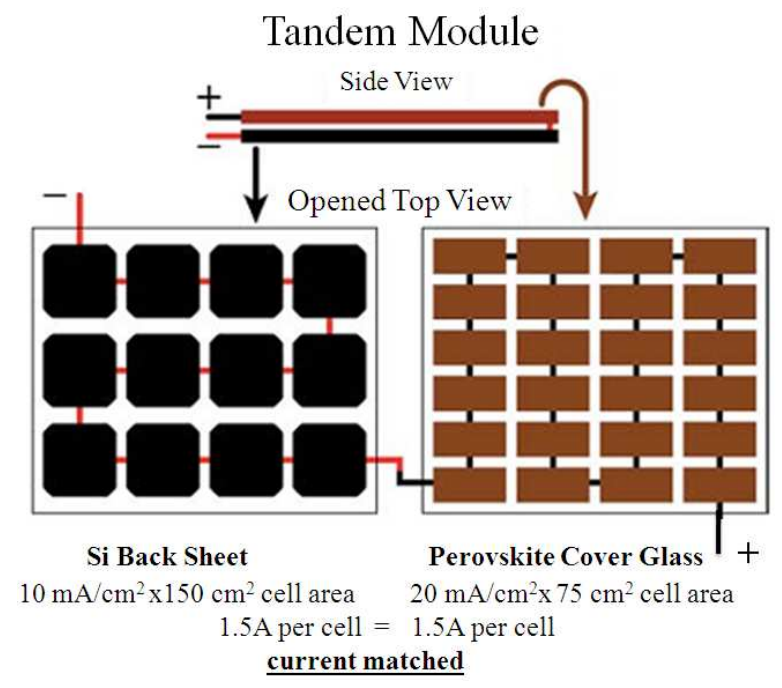

Figure 8. Current-matching at the module level.

An example perovskite/silicon module with a simplified geometry and current density to demonstrate how currentmatching at the module level can ocur with a mechanically- 
stacked tandem. In this example module, the filtered silicon produces half the photocurrent density of the perovskite, so the silicon cells are twice as large to match the current of the perovskite cells. In this example, all cells are strung together in series; the total voltage of the module is the sum of the individual cell voltages [14]. This configuration allows the module to have only two leads exiting the module and requires only a single inverter, similar to conventional single-junction modules. However, a monolithic tandem requires the engineering of a tunnel junction or recombination layer, the likely need to planarize the surface of the bottom cell to build the perovskite cell, and photon management within the complicated dielectric stack. Bailie et al. have achieved a mechanically-stacked tandem by using a semi-transparent perovskite solar cell as the top cell on top of Si and CIGS and provide an outlook for the potential of polycrystalline tandems. Perovskite solar cells are already efficient enough to upgrade the performance of silicon solar cells made with low-quality silicon using the polycrystalline tandem approach. The current-voltage curves and external quantum efficiency of the semi-transparent perovskite solar cell, the CIGS solar cell and
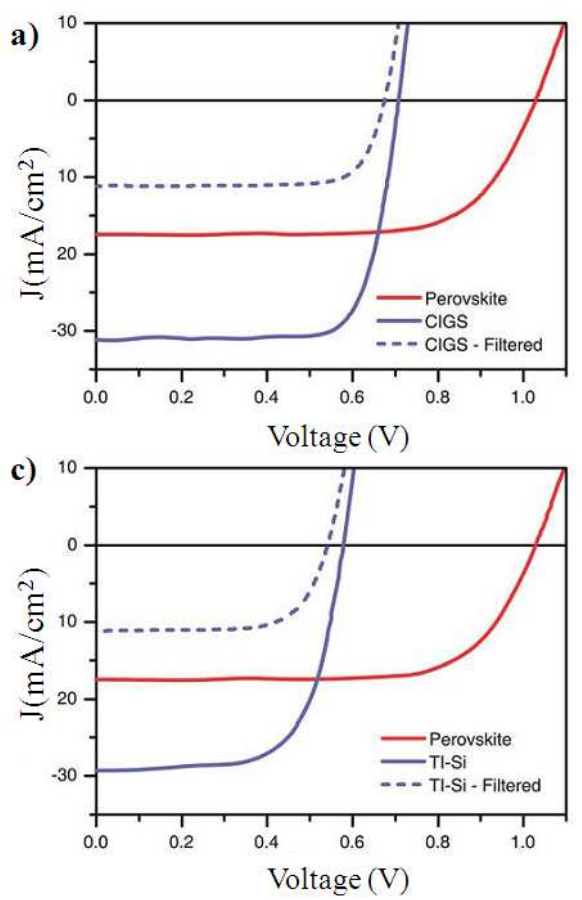

the CIGS solar cell underneath the perovskite solar cell are shown in Fig. 9. To arrive at the efficiency of the 4-terminal tandem, the efficiency of the semi-transparent perovskite cell is added to the efficiency of the CIGS solar cell when underneath the perovskite cell. With $12.7 \%$ semi-transparent perovskite cell, they improved the $17.0 \%$ CIGS cell to $18.6 \%$ in a tandem (Figures 9a and b/Table 5) as measured in house. They explored lower quality sources of $\mathrm{Si}$ including cast multicrystalline silicon (mc-Si) wafers made from feedstock with high impurity content recycled from the top $10 \%$ of other cast multicrystalline ingots (TI-Si) (Figures 9c-d /Table 5) and cast mc-Si wafers grown using $4.5 \mathrm{~N}(99.995 \%$ pure) upgraded metallurgical-grade $\mathrm{Si}$ (UMG-Si) instead of the more expensive Siemens-grade polysilicon (9 N, or $99.9999999 \%$ pure). Low quality $\mathrm{Si}$ sources generally are not commercially viable today in single-junction devices because the material cost advantage of low-quality $\mathrm{Si}$ is offset by the reduction in performance due to impurities and crystal defects. An improvement has been achieved from $11.4 \%$ low-quality $\mathrm{Si}$ cell to $17.0 \%$ as a tandem, a remarkable relative efficiency increase of nearly $50 \%$ [14].
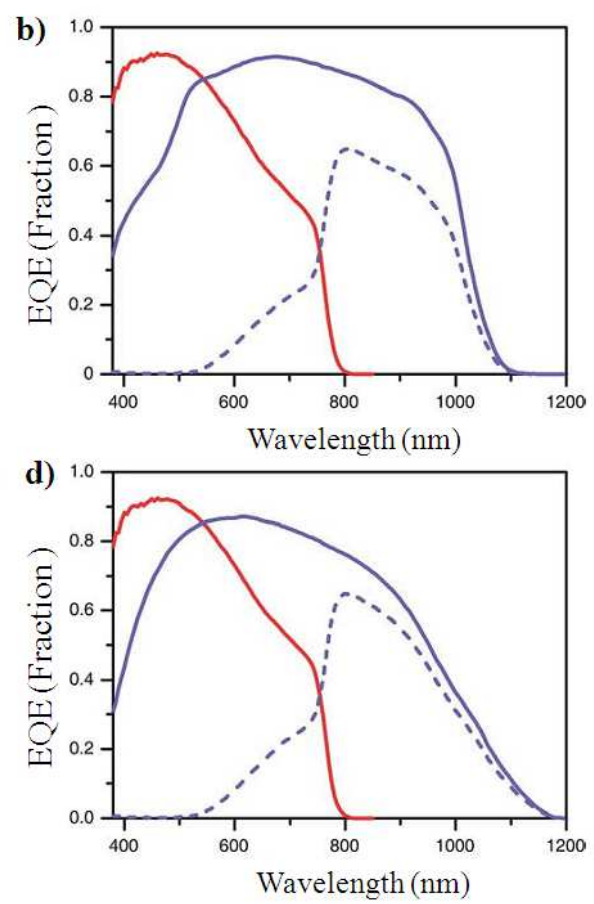

Figure 9. Perovskite and CIGS/Si tandem results. a) Current-voltage and b) EQE of semi-transparent perovskite cell, unfiltered CIGS cell, and CIGS cellfiltered by the perovskite cell. c) I-Vcurves and d) EQE of semi-transparent perovskite cell, unfiltered TI-Si cell, and TI-Si cell with an infraredoptimized anti-reflection coatingfiltered by the perovskite cell [14].

Table 5. Performance metrics of semi-transparent perovskite cell, CIGS cell, TI-Si cell, and the resulting tandem efficiencies [14].

\begin{tabular}{lllll}
\hline & Jsc $\left(\mathbf{m A c m} \mathbf{c}^{-2}\right)$ & Voc(mV) & FF (\%) & Efficiency (\%) \\
\hline Semi-transparent perovskite & 17.5 & 1025 & 0.710 & 0.667 \\
TI-Si-unfiltered & 29.3 & 582 & 0.704 & 11.4 \\
TI-Si w/IR-ARC-filtered & 11.1 & 547 & 4.3 \\
Tandem w/perovskite + TI-Si & & & 0.768 & 17.0 \\
CIGS-unfiltered & 31.2 & 711 & 0.788 & 17.0 \\
CIGS- filtered & 10.9 & 682 & 5.9 \\
Tandem w/perovskite + CIGS & & & 18.6 \\
\hline
\end{tabular}

From a different view, tandem layout of solar cells, wherein two or more sub-cells with complementary 
absorption characteristics are stacked and connected either in series or in parallel, is one of the exciting applications to increase the efficiency effectively of solar cells beyond the Shockley-Queisser limit of single-junction devices [67-69]. For example, dual- and triple-junction solar cells based on III-V compound semiconductor materials such as InGaP/GaAs/InGaAs have been demonstrated to show over $37 \%$ power conversion efficiency (PCE) [9]. In addition to the tandem structure achieved with similar class materials, two substantially different PV materials have also been incorporated into tandem solar cell construction. For example, tandem solar cells fabricated with a-Si and a polymer have been demonstrated to show enhanced voltage and power conversion efficiency compared to conventional single-junction solar cells [70-72]. Furthermore, the tandem architecture of a DSSC with GaAs or polymer is reported to show high voltages of 1.8 and $1.36 \mathrm{~V}$, respectively $[73,74]$. Recently, Liska et al. and Wenger et al. suggested the possibility of a tandem type of architecture with DSSC and CIGS based on mechanical stacking as well as a monolithic conjunction $[57,75]$. Such a tandem construction of DSSC with CIGS seems to be an ideal design owing to the optical band-gaps of DSSC $(\sim 1.7 \mathrm{eV})$ and CIGS $(\sim 1.1 \mathrm{eV})$, making them suitable for use as top and bottom cells, respectively (see Figure 1e). In addition, from the viewpoint of manufacturing costs, the DSSC/CIGS tandem solar cell would be a competitive option, given the advantage of the economic viability of DSSCs prepared by solution processes. However, to realize a further reduction in the cost of DSSC/CIGS tandem solar cells, it is necessary to develop low-cost and high-throughput solution processing methods (e.g., printing) for the fabrication of the bottom CIGS cell, which is currently fabricated by a vacuum-based method such as co-evaporation. Recently, solution-based fabrication methods for CIGS thin films have attracted much attention due to their potential for realizing low-cost and printable solar cells [76]. The highest efficiencies of solution processed

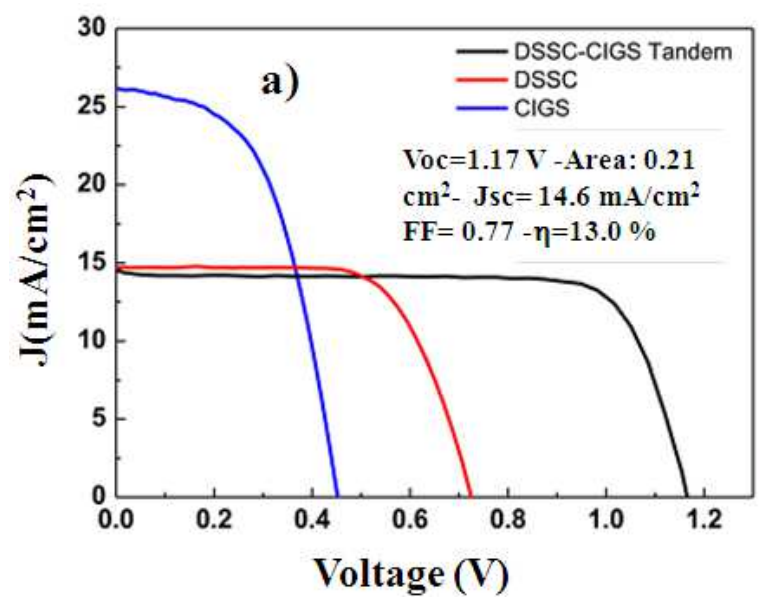

CIGS thin film solar cells have been reported to be $15.2 \%$ (hydrazine based) [77] and 12\% (non-hydrazine based) [78] One of the major issues in the fabrication of efficient tandem DSSC/CIGS cells (Figure 1e) is to control the electrical/optical properties of the interface between the DSSC and the CIGS. So, the role of the Pt catalytic layer is effectively to reduce the over potential for the reduction of the $\mathrm{I}^{3-}$ ions to $\mathrm{I}^{-}$ions by the photoelectrons coming out from the underneath CIGS solar cell. However, Pt catalytic layer inevitably decreases the optical transmittance, which should lead to a decrease in the photocurrent from the bottom cell and to a photocurrent mismatch in the tandem cell. Therefore, it is desirable to prepare Pt catalysts with high catalytic properties and high optical transmittance simultaneously [12].

Figures $(10 \mathrm{a}, \mathrm{b})$ show the $\mathrm{J}-\mathrm{V}$ characteristics and external quantum efficiencies with spectral irradiance of the DSSC/CIGS tandem solar cell along with the DSSC and CIGS single-junction solar cells. The as-fabricated DSSC/CIGS tandem cell showed a power conversion efficiency of $13.0 \%$ with an open circuit voltage $\left(\mathrm{V}_{\mathrm{OC}}\right)$ of $1.17 \mathrm{~V}$, a short-circuit current density $\left(\mathrm{J}_{\mathrm{SC}}\right)$ of $14.6 \mathrm{~mA} / \mathrm{cm}^{2}$, and a fill factor (FF) of 0.77. The measured $\mathrm{V}_{\mathrm{OC}}$ of the tandem cell $(1.17 \mathrm{~V})$ was in fairly good agreement with the sum of the individual average $\mathrm{V}_{\mathrm{OC}}$ values for DSSC and CIGS single-junction cells $(1.18 \mathrm{~V})$. The plateau value of JSC for the tandem device $\left(14.2 \mathrm{~mA} / \mathrm{cm}^{2}\right)$ was slightly lower than that of the DSSC $\left(14.7 \mathrm{~mA} / \mathrm{cm}^{2}\right)$. The $\mathrm{J}_{\mathrm{SC}}$ of CIGS bottom cell in the tandem configuration cannot be measured with two terminal electrodes (on top of the DSSC and at the bottom of the CIGS). It is also far from simple to estimate it by covering the CIGS with a dummy DSSC cell, due to the difficulties in applying DSSC components identical to those used for the top cell in the tandem structure. Nevertheless, the observation that the $\mathrm{J}_{\mathrm{SC}}$ of tandem cell is too close to that of the DSSC suggests that the $\mathrm{J}_{\mathrm{SC}}$ values from both sub-cells are well balanced [12].

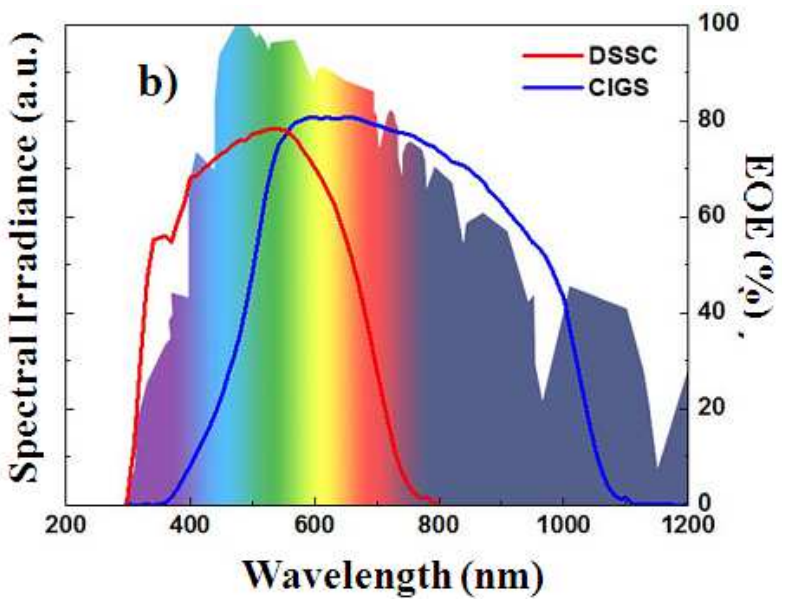

Figure 10. a) Current density-voltage (J-V) characteristics of DSSC/CIGS tandem solar cell and DSSC and CIGS single-junction solar cells under 1sun illumination. b) Spectral irradiance of solar light adapted from reference [68] and external quantum efficiencies of a DSSC (red) and a CIGS (blue) singlejunction solar cell used in the study (bottom) [12].

All these new insights and techniques showed that great/novel applications of CIGS photovoltaic solar cells have been well established over the past 5-6 years and all 
these attempts merely illustrate the feasibility of many possible approaches to design/growth of new CIGS containing materials schemes easily reproducible and thus increased PV production scale is expected to drive down costs across technologies.

Ultimately, we need to know at what point a chosen deposition or processing approach becomes the dominant factor for limiting product performance. Building-integrated products may provide a significant entry channel for CIGS thin-film cells, taking advantage of the demonstrated capability to manufacture flexible cells (e.g., Global Solar, DayStar, Miasole, Ascent Solar, NanoSolar, ISET, and SoloPower) and the potential to conform the film PV to building-material geometries. The absence of glass encapsulation systems drives a second high-priority development to address the inherent device sensitivity to water vapor. Developing a low-cost, flexible, transparent package for CIGS that will assure long period outdoor module lifetime constitutes an enabling prerequisite for addressing this business segment [79]. Start-up companies have selected a multitude of processing approaches, which provides both an opportunity as well as a challenge to improve commercial module efficiency.

Some applications of photovoltaic solar cells that have been well established over the past 50 years include; (i) supplying power in remote locations e.g. for communications and weather monitoring systems and the lighting and water pumping systems used in developing countries, (ii) supplying power for consumer products e.g. for electronic calculators and garden lights, (iii) supplying power for applications in space e.g. for satellites and space vehicles (Figure) [80].

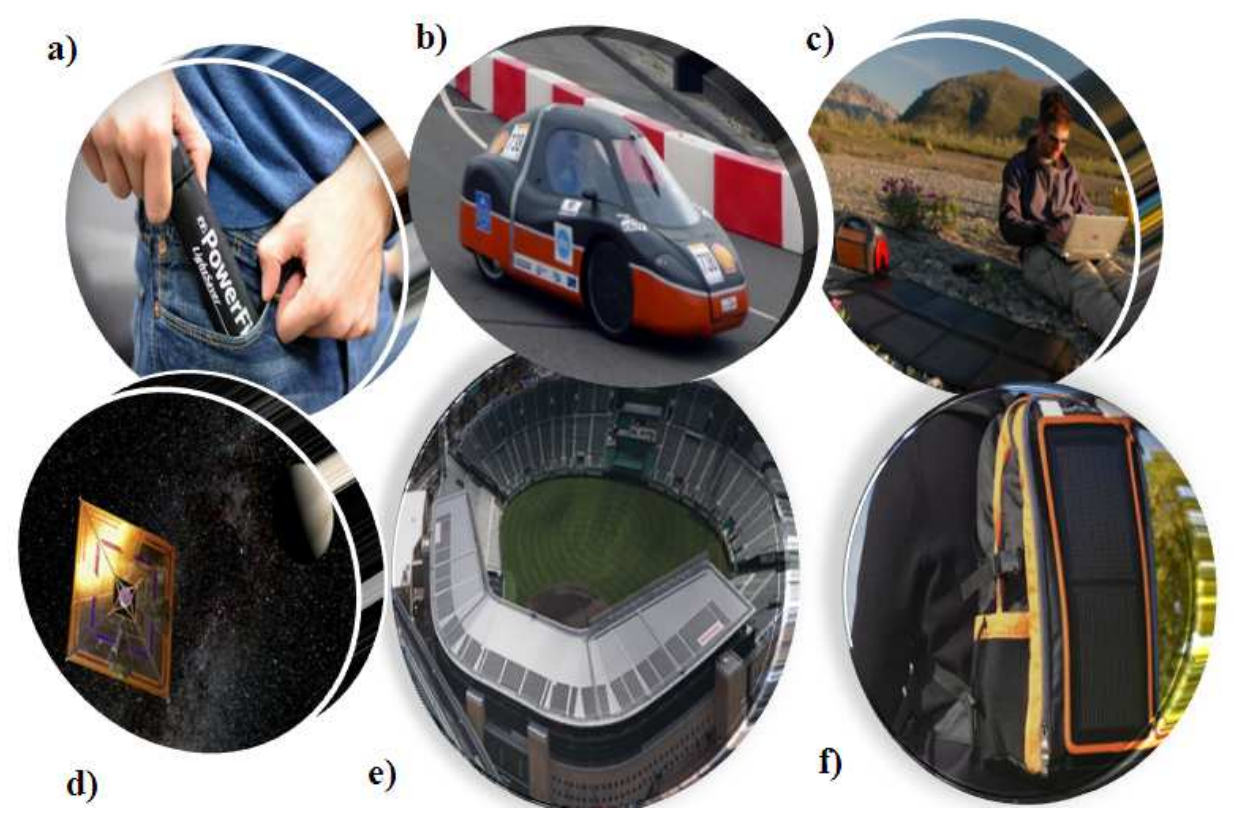

Figure 11. Some applications of PVs: a) Powerfilm panels for usage in LightSaver Pocket applications (www.powerfilmsolar.com) b) The Swedish Royal Institute of Technology (KTH) has set a new fuel efficiency record of $181.5 \mathrm{~km} / \mathrm{kWh}$ in the Shell Eco Marathon competition for a CIGS powered car called 'Elba' (www.enginetechnologyinternational.com-2016) c) Civilian uses for lightweight, flexible CIGS solar modules include battery charging and portable power for PDAs, cell phones and laptop computers (Photo courtesy of Global Solar Inc.-2016) d) A solar yacht to Venus needing reliable power for instrumentation (powerfilmsolar.com/custom/solar-yacht -2016) e) Hanshin Koshien Stadium installed with CIGS thin film solar panels in Sweden (world.honda.com/power/solar-2016) f) Ascent's EnerPlex Packr Solar Backpack (www.ascentsolar.com).

\section{Conclusions}

Under these circumstances around the world, scientists/engineers in big-scale companies are investing in solar generation capacity to uplift, and, as a consequence, costs continue to fall and technologies improve. This publication gives an authoritative view of these technologies and trends in chalcopyrites, in both advanced and developing techniques, while providing examples of the best and most advanced practices with a sensitive analyze around these metrics. It also provides a unique guide for manufacturers, industry representatives and concerned stakeholders on how best to use, combine and successfully promote the major categories of chalcopyrite PV materials, finally, in analysing the likely evolution of chalcopyrites - it explores the leading role solar energy materials could play in the long-term future of our energy materials aspect.

\section{References}

[1] P. Jackson, D. Hariskos, E. Lotter, S. Paetel, R. Wuerz, R. Menner, W. Wischmann, M. Powalla, Prog. Photovoltaics 19 (7) (2011) 894-897.

[2] Raid A. Ismail, Omar A. Abdulrazaq, Sol. Energy Mater. Sol. Cells 91 (10) (2007) 903-907.

[3] First Solar, media release from Aug. 5, 2014 http://investor.firstsolar.com/releasedetail.cfm?ReleaseID=864 426, 2014. 
[4] Cephas E. Small, Song Chen, Jegadesan Subbiah, Chad M. Amb, Sai-Wing Tsang, Tzung-Han Lai, John R. Reynolds, Franky So Nature Photonics 6, (2012) 115-120.

[5] G. A. Pattantyus-Abraham, I. J. Kramer, A. R. Barkhouse, X. Wang, G. Konstantatos, R. Debnath, L. Levina, I. Raabe, M. K. Nazeeruddin, M. Grätzel, E. H. Sargent ACS Nano 4 (6) (2010) 3374-3380.

[6] J. A. Aguiar, S. Wozny, T. G. Holesinger, T. Aoki, M. K. Patel, M. Yang, J. J. Berry, M. Al-Jassim, W. Zhou, K. Zhu Energy Environ. Sci. 9 (2016) 2372-2382.

[7] S. Albrecht, M. Saliba, J. P. Correa Baena, F. Lang, L. Kegelmann, M. Mews, L. Steier, A. Abate, J. Rappich, L. Korte, R. Schlatmann, M. K. Nazeeruddin, A. Hagfeldt, M. Grätzel, B. Rech Energy Environ. Sci. 9 (2016) 81-88.

[8] J-H. Yoon, J-K Park, W. M. Kim, J. W. Lee, H. Pak, J, -hyun Jeon Scientific Reports 7690 (2015) 1-9.

[9] M. A. Green, K. Emery, Y. Hishikawa, W. Warta, E. D. Dunlop, Prog. Photovolt.: Res. Appl. 22 (2014) 1-9.

[10] L. Fraas, L. Partain Solar Cells and Their Applications (2010) 2nd Ed. John Wiley \& Sons, Inc. New Jersey, US.

[11] International Energy Agency Report: New IEA study assesses solar technologies and shows how an integrated approach will increase efficiency, foster deployment and reduce costs11.1.2011.

[12] S. H. Moon, S. J. Park, S. H. Kim, M. W. Lee, J. Han, J. Y. Kim, H. Kim, Y. J. Hwang, D.-K. Lee, B. K. Min Scientific Reports 5 (2015) 8970.

[13] L. Yin, K. Zhang, H. Luo, G. Cheng, X. Ma, Z. Xiong, X. Xiao Nanoscale 6 (2014) 10879-10886.

[14] C. D. Bailie, M. G. Christoforo, Jo. P. Mailoa, A. R. Bowring, E. L. Unger, W. H. Nguyen, J. Burschka, N. Pellet, J. Z. Lee, M. Gratzel, R. Noufi, T. Buonassisi, A. Salleo, M. D. McGehee, Energy Environ Sci. 8 (2015) 956-963.

[15] T. Feurer, P. Reinhard, E. Avancini, B. Bissig, J. Löckinger, P. Fuchs, R. Carron, T. P. Weiss, J. Perrenoud, S. Stutterheim, S. Buecheler, A. N. Tiwari Prog. Photovolt. Res. Appl. 3 Oct, 2016.

[16] Y-K. Liao, M. Brossard, D.-H. Hsieh, T.-N. Lin, M. D. B. Charlton, S.-J. Cheng, C.-H. Chen, J-L. Shen, L.-T. Cheng, T. P. Hsieh, F.-I Lai, S.-Y Kuo, H-C. Kuo, P. G. Savvidis, P. G. Lagoudakis Adv. Energy Mater (2014) 1401280.

[17] S. Wagner, J. L. Shay, P. Migliorato, Appl. Phys. Lett. 25 (8) (1974) 434-435.

[18] P. Jackson, D. Hariskos, E. Lotter, S. Paetel, R. Wuerz, R. Menner, W. Wischmann, M. Powalla, Prog. Photovolt. Res. Appl. 2011.

[19] I. Repins, M. A. Contreras, B. Egaas, C. DeHart, J. Scharf, C. L. Perkins, B. To, and R. Noufi, Prog. Photovolt. Res. Appl. 16 (2008) 235-239.

[20] R. N. Bhattacharya, W. Batchelor, J. F. Hiltner, J. R. Sites, Appl. Phys. Lett. 75 (1999) 1431.

[21] V. K. Kapur, G. P Ceasar, R. D. McConnell, A. Rohatgi, D. Carlson Photovoltaics for the 21st Century: Proceedings of the International Symposium (1999), The Electrochemical Society Inc. Pennington NJ-USA.
[22] R. N. Bhattacharya, J. F. Hiltner, W. Batchelor, M. A. Contreras, R. N. Noufi, J. R. Sites Thin Solid Films 361-362 (2000) 396-399.

[23] D. Lincot, J. F. Guillemoles, S. Taunier, D. Guimard, J. SicxKurdi, A. Chaumont, O. Roussel, O. Ramdani, C. Hubert, J. P. Fauvarque, N. Bodereau, L. Parissi, P. Panheleux, P. Fanouillere, N. Naghavi, P. P. Grand, M. Benfarah, P. Mogensen, O. Kerrec, Sol. Energy, 77 (2004) 725.

[24] A. Duchatelet, T. Sidali, N. Loones, G. Savidand, E. Chassaing, D. Lincot, Sol. Energy Mater. Sol. Cells 119 (2013) 241.

[25] S. Aksu, S. Pethe, A. Kleiman-Shwarsctein, S. Kundu, M. Pinarbasi, in Proceedings of 38th IEEE Photovoltaic Specialists Conference (PVSC), IEEE (2012) 003092-97.

[26] V. Bermudez (Nexcis), presented at 5th Photovoltaics ThinFilm Week, Berlin, Apr. 2013.

[27] C. Broussillou, M. Andrieux, M. Herbst-Ghysel, M. Jeandin, J. S. Jaime-Ferrer, S. Bodnar, E. Morin, Sol. Energy Mater. Sol. Cells 95 (2011) S13.

[28] F. Oliva, C. Broussillou, M. Annibaliano, N. Frederich, P. P. Grand, A. Roussy, P. Collot, S. Bodnar, Thin Solid Films 535 (2013) 127.

[29] A. Chirila, P. Reinhard, F. Pianezzi, P. Bloesch, A. R. Uhl, C. Fella, L. Kranz, D. Keller, C. Gretener, H. Hagendorfer, D. Jaeger, R. Erni, S. Nishiwaki, S. Buecheler, A. N. Tiwari, Nat. Mater. 12 (2013) 1107.

[30] Y. E. Romanyuk, H. Hagendorfer, P. Stücheli, P. Fuchs, A. R. Uhl, C. M. Sutter-Fella, M. Werner, S. Haass, J. Stückelberger, C. Broussillou, P.-P. Grand, V. Bermudez, A. N. Tiwari Adv. Funct. Mater. 25 (2015) 12-27.

[31] J. A. Frantz, R. Y. Bekele, V. Q. Nguyen, J. S. Sanghera, A. Bruce, S. V. Frolov, M. Cyrus, and I. D. Aggarwal, Thin Solid Films 519 (2011) 7763.

[32] C. H. Chen, W. C. Shih, C.-Y. Chien, C.-H. Hsu, Y.-H. Wu, C. H. Lai, Sol. Energy Mater. Sol. Cells 103 (2012) 25.

[33] J. H. Shi, Z. Q. Li, and S. M. Huang, Prog. Photovolt: Res. Appl. 19 (2011) 160.

[34] X. L. Zhu, Y.M. Wang, Z. Zhou, A.M. Li, L. Zhang, F. Q. Huang, Solar Energy Materials \& Solar Cells 113 (2013) 140-143.

[35] J. Liu, D. M. Zhuang, and X. L. Li, Prog. Nature Sci. 23 (2013) 133.

[36] S. Fiat Varol, E. Bacaksı, P.Koralli, M. Kompitsas, G. Çankaya, Mat. Lett. 142 (2015) 273-276.

[37] National Solar Technology Roadmap: CIGS PV, National Renewable Energy Laboratory, Sandia National Laboratories, U.S. Depart. of Energy 2007.

[38] A. Rockett, R.N. Bhattacharya, V. Kapur, S.H. Wei, Basic Research Opportunities in Cu-Chalcopyrite Photovoltaics, Electrochemical Society International Symposium Seattle, Washington May 2-6, 1999.

[39] W. Han, Z. Lin, Angew. Chem. Int. Ed. 51 (2012) 1534.

[40] MiaSole Comm., Efficiency with Commercial-Scale CIGS Thin Film Solar Modules, Dec. 02, 2010. 
[41] TSMC solar press release, TSMC solar commercialsize modules $\left(1.09 \mathrm{~m}^{2}\right)$ Set CIGS $15.7 \%$ efficiency record, June 18,2013 .

[42] H. Sugimoto, T. Yagioka, M. Nagahashi, Y. Yasaki, Y. Kawaguchi, T. Morimoto, Y. Chiba, T. Aramoto, Y. Tanaka, H. Hakuma, S. Kuriyagawa, K. Kushiya, Achievement of over $17 \%$ efficiency with $30 \times 30 \mathrm{~cm}^{2}$-sized $\mathrm{Cu}$ (In, Ga) (Se, S $)_{2}$ submodules, 37th IEEE Photovoltaic Specialist Conference, Seattle, June 19-24, 2011.

[43] Hanergy Solar Group Limited press release, Voluntary announcement achievement of thin film efficiency of $18.7 \%$ with Solibro's CIGS thin film technology, Hong Kong, Oct 7. 2013.

[44] EMPA press release, A new world record for solar cell efficiency, 18. Jan. 2013.

[45] M. Powalla, P. Jackson, W. Witte, D. Hariskos, S. Paetel, C. Tschamber, W. Wischmann Sol. Energy Mater. Sol. Cells 119 (2013) 51-58.

[46] MA. Contreras, J. Turtle, A. Gabor, A. Tennant, K. Ramanathan, S. Ashner, A. Franz, J. Keane, L. Wang, J. Scofield, R. Noufi High efficiency $\mathrm{Cu}$ (In, Ga) $\mathrm{Se}_{2}$ based solar cells: processing of novel absorber structures. Proceedings of the First WCPEC Hawaii, Dec. 5-9, 1994.

[47] S. Niki, M. Contreras, I. Repins, M. Powalla, K. Kushiya, S. Ishizuka, K. Matsubara Prog. Photovolt.: Res. Appl. 18 (2010) 453-466.

[48] M. P. Pedro Salome, V. Fjallstrom, P. Szaniawski, J. P. Leitao, A. Hultqvist, P. A. Fernandes, J. P. Teixeira, B. P. Falcao, U. Zimmermann, A. F. da Cunha, M. Edoff Prog. Photovolt: Res. Appl. 23 (2015) 470-478.

[49] R. Mainz, E. S. Sanli, H. Stange, D. Azulay, S. Brunken, D. Greiner, S. Hajaj, M. D. Heinemann, C. A. Kaufmann, M. Klaus, Q. M. Ramasse, H. Rodriguez-Alvarez, A. Weber, I. Balberg, O. Millo, P. A. van Aken, D. Abou-Ras En. Environ. Sci 9 (2016) 1818-1827.

[50] Y. Cui, A. Javey, J. Benner BAPVC Annual Project Report 2015.

[51] R. C. Armstrong, C. Wolfram, K. P. de Jong, R. Gross, N. S. Lewis, B. Boardman, A. J. Ragauskas, K. Ehrhardt-Martinez, G. Crabtree and M. Ramana Nat. Energy 1 (2016) 15020.

[52] J. Pohl and K. Albe J. Appl. Phys. 108 (2010) 023509.

[53] NREL Efficiency Chart Rev. Sept. 12, 2014, NREL.

[54] A. Kojima, K. Teshima, Y. Shirai, T. Miyasaka J. Am. Chem. Soc. 131 (2009) 6050-6051.

[55] T. J. Coutts, K. A Emery, J. S. Ward Prog. Photovolt: Res. Appl. 10 (2002) 195-203.

[56] X. Wu, J. Zhou, A. Duda, J. C. Keane, T. a. Gessert, Y. Yan and R. Noufi Prog. Photovolt. 14 (2006) 471-483.

[57] P. Liska, K. R. Thampi, M. Gratzel, D. Bremaud, D. Rudmann, H. M. Upadhyaya. N. Tiwari Appl. Phys. Lett. 88 (2006) 203103.

[58] J. Burschka, N. Pellet, S.-J. Moon, R. Humphry-Baker, P. Gao, M. K. Nazeeruddin and M. Gratzel Nature, 499 (2013) 316-319.

[59] M. Liu, M. B. Johnston and H. J. Snaith Nature 501 (2013) 395-398.
[60] Q. Chen, H. Zhou, Z. Hong, S. Luo, H.-S. Duan, H.-H. Wang, Y. Liu, G. Li and Y. Yang J. Am. Chem. Soc. 136 (2013) 622625 .

[61] G. Xing, N. Mathews, S. Sun, S. S. Lim, Y. M. Lam, M. Gr"atzel, S. Mhaisalkar and T. C. Sum Science 342 (2013) 344-347.

[62] T. Umebayashi, K. Asai, T. Kondo and a. Nakao Phys. Rev. B: Condens. Matter Mater. Phys. 67 (2003) 155405.

[63] C. C. Stoumpos, C. D. Malliakas and M. G. Kanatzidis, Inorg. Chem. 52 (2013) 9019-9038.

[64] W.-J. Yin, T. Shi and Y. Yan, Appl. Phys. Lett. 104 (2014) 063903.

[65] V. Gonzalez-Pedro, E. J. Juarez-Perez, W.-S. Arsyad, E. M. Barea, F. Fabregat-Santiago, I. Mora-Sero and J. Bisquert Nano Lett. 14 (2014) 888-893.

[66] J. H. Noh, S. H. Im, J. H. Heo, T. N. Mandal and S. Il Seok Nano Lett. 13 (2013) 1764-1769.

[67] W. Shockley, H. J. Queisser J. Appl. Phys. 32 (1961) 510 519.

[68] A. Devos J. Phys. D: Appl. Phys. 13 (1980) 839-846.

[69] D. Dimova-Malinovska J. Phys: Conf. Ser. 250 (2010) 012007-15.

[70] K. Taehee; J. Jun Hong, H., Seunghee, L. Doh-Kwon, K. Honggon, L. Wonmok, K. Kyungkon Appl. Phys. Lett. 98 (2011) 183503-3.

[71] J. Hoon Seo, D.-H. Kim, S.-H. Kwon, M. Song, M.-S. Choi, S. Y. Ryu, H. W. Lee, Y. C. Park, J.-D. Kwon, K.-S. Nam, Y. Jeong, J.-W. Kang, C. Su Kim Adv. Mater. 24 (2012) 4523 4527.

[72] M. Reinhard, P. Sonntag, R. Eckstein, L. Bürkert, A. Bauer, B. Dimmler, U. Lemmer, A. Colsmann Appl. Phys. Lett. 103 (2013) 143904-4.

[73] S. Ito, I. M. Dharmadasa, G. J. Tolan, J. S. Roberts, G. Hill, H. Miura, J.-H. Yum, P. Pechy, P. Liska, P. Comte, M. Grätzel Sol. Energy 85 (2011) 1220-1225.

[74] I. Bruder, M. Karlsson, F. Eickenmeyer, J. Hwang, P. Erk, A. Hagfeldt, J. Weis, N. Pschirer Sol. Energ. Mat. Sol. C. 93 (2009) 1896-1899.

[75] S. Wenger, S. Seyrling, A. N. Tiwari, M. Gratzel, Appl Phys. Lett. 94 (2009) 173508-3.

[76] S. E. Habas, H. A. S. Platt, M. van Hest, D. S. Ginley, Chem. Rev. 110 (2010) 6571-6594.

[77] T. K. Todorov, O. Gunawan, T. Gokmen, D. B. Mitzi Prog. Photovolt.: Res. Appl. 21 (2013) 82-87.

[78] Q. Guo, G. M. Ford, R. Agrawal, H. W. Hillhouse Prog. Photovolt.: Res. Appl. 21 (2013) 64-71.

[79] National Solar Technology Roadmap: CIGS PV, NREL Jun. 2007.

[80] L. D. Partain Solar Cells and Their Applications, John Wiley \& Sons, 1995. 


\section{Biography}

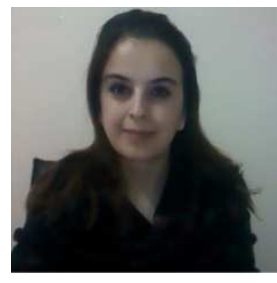

Songül Fiat Varol is currently Associate Professor in Energy Systems Engineering at Giresun University. She pursues a broad range of research interests that include Solar Cells, Schottky Diodes, Light Emitting Diodes (LEDs), Organic Light Emitting Diodes (OLEDs), PN Homojunctions/Heterojunctions, Thin Films, Nanofabrication/ Nanocharacterization.

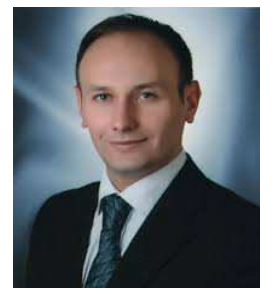

Güven Çankaya is a professor of Materials Science Engineering at Ankara Yıldırım Beyazit University. He is also director of Medical Metrology Application and Research Center since 2013. His work focuses specifically on the R\&D on the production of nanomaterials, semiconductors (diode and solar cell) and smart materials also includes investigation electrical, optical, morphological and structural properties of such devices fabricated on this scale. 